\title{
Influence of microstructural and morphological properties of raw natural clays on the reactivity of clay brick wastes in a cementitious blend matrix
}

\section{(Influência das propriedades microestruturais e morfológicas de argilas in natura na reatividade de resíduos de tijolos em uma matriz cimentícia)}

\author{
A. Schackow ${ }^{*}$, S. L. Correia ${ }^{2}$, C. Effting ${ }^{1}$ \\ ${ }^{I}$ State University of Santa Catarina, Center of Technological Sciences, Department of Civil Engineering, Civil \\ Engineering Graduate Program, 89219-710, Joinville, SC, Brazil \\ ${ }^{2}$ State University of Santa Catarina, Center of Technological Sciences, Materials Science and Engineering \\ Graduate Program, 89219-710, Joinville, SC, Brazil
}

\begin{abstract}
The physical, chemical, and mineralogical characteristics of raw clays used in the industries interfere greatly in the production process and final ceramic product. Raw clays from 4 industries in the South of Brazil were characterized by the XRD, XRF, FTIR, DSC, and SEM techniques. In addition, the pozzolanic potential was also verified based on the kaolinite content of the raw samples. The raw clay that presented the highest pozzolanic potential had a quantity of kaolinite of $69.7 \%$. The use of $40 \%$ of the brick waste produced with this raw clay (particle size of $75 \mu \mathrm{m}$ ) replacing Portland cement in a mortar resulted in a gain of $51 \%$ in compressive strength at 28 days. The analysis of the hydration products resulting from the $\mathrm{Ca}(\mathrm{OH})_{2}$ reaction from the cement hydration with the ceramic waste showed the presence of $\mathrm{Al}_{2} \mathrm{O}_{3} \cdot 2 \mathrm{SiO}_{2}$ forming the $\mathrm{C}-\mathrm{S}-\mathrm{H}$ gel.
\end{abstract}

Keywords: raw clay characterization, clay brick waste, clay microstructure, pozzolanic clay, cement hydration product.

\section{Resumo}

Características físicas, químicas e mineralógicas das argilas in natura utilizadas nas indústrias interferem no processo produtivo e produto cerâmico final. Foram caracterizadas argilas in natura de 4 indústrias do Sul do Brasil pelas técnicas de DRX, FRX, FTIR, DSC e MEV. Além disso, o potencial pozolânico também foi verificado com base no teor de caulinita das amostras in natura. A argila que apresentou o maior potencial pozolânico teve quantidade de caulinita de 69,7\%. O uso de 40\% de resíduo de tijolo produzido com esta argila (tamanho de partícula de $75 \mu \mathrm{m}$ ) substituindo cimento Portland em uma argamassa resultou em aumento de $51 \%$ na resistência à compressão em 28 dias. A análise dos produtos de hidratação resultantes da reação de $\mathrm{Ca}(\mathrm{OH})_{2}$ da hidratação do cimento com o resíduo cerâmico mostrou a presença de $\mathrm{Al}_{2} \mathrm{O}_{3} .2 \mathrm{SiO}_{2}$ formando o gel de $\mathrm{C}-\mathrm{S}$ - $\mathrm{H}$.

Palavras-chave: caracterização de argila, resíduo de tijolo cerâmico, microestrutura de argila, material pozolânico, produto de hidratação do cimento.

\section{INTRODUCTION}

Knowledge of the main characteristics of ceramic raw materials is important during the development and production stages of any ceramic product. Physical and mechanical properties of structural ceramic products depend on the physical, chemical, and mineralogical characteristics of the different kinds of raw materials, which also control the overall processing of the unfired and fired bodies [1, 2]. Some byproducts such as fly ash and ground granulated blast-furnace slag can be used as activators in the unfired clay brick technology and influence the properties of structural ceramic products [3]. During the processing of

*adilson.schackow@udesc.br

Dhttps://orcid.org/0000-0003-2561-5231 traditional ceramic products (brick, porcelain, tiles), the raw clays contribute to the plasticity and green strength required at the forming stage. Clay minerals are formed by the decomposition of feldspathic rocks by geological processes. Kaolinite, the most common clay mineral, is a 1:1 sheet silicate composed of alternating layers of $\left[\mathrm{Si}_{2} \mathrm{O}_{5}\right]^{2-}$ and $\left[\mathrm{Al}_{2}(\mathrm{OH})_{4}\right]^{2+}$. Kaolinitic clays usually contain kaolinite together with other minerals such as smectite, illite, micas, and 2:1 sheet silicates of variable composition [4-8]. The physical, chemical and mineralogical characteristics of raw clays depend on their geological history and location [9], and there is an increasing need for new studies related to the characterization of raw clays from different locals for traditional ceramic products. Wastes with pozzolanic characteristics such as fly ash, silica fume, sludge, and ceramics $[10,11]$ have been used as partial replacement 
of Portland cement. The use of red ceramic brick waste as cementitious materials has been studied by several authors $[12,13]$. The main advantage of this residue is that it has already gone through a firing process (usually between 600 and $900{ }^{\circ} \mathrm{C}$ ), which results in metakaolinite in this waste.

This study describes the chemical and mineralogical characterization of 4 clays raw materials mined from different regions of the North of the Santa Catarina State, Brazil, seeking to find new applicability in the ceramic industry and other sectors. There are practically no studies on the clays from this local, and little information has been published about the characteristics of these materials. Furthermore, after determining which raw clay has the greatest pozzolanic potential, an application of this clay (after firing and in the form of ground brick) in a building mortar was tested. It was possible to verify the influence of the properties of the raw clay on the reactivity with $\mathrm{Ca}(\mathrm{OH})_{2}$ from the cement hydration in a mortar.

\section{MATERIALS AND METHODS}

Materials: the raw clays used in this study were obtained from different sources after mining, which are used for the production of structural brick at 4 industries located in different cities in the North of Santa Catarina (Brazil): Joinville (industries A and B), Garuva (industry C), and São Bento do Sul (industry D). Table I shows some data related to the production of these companies. Samples of the clayey masses used in these industries were dried in an oven at $100{ }^{\circ} \mathrm{C}$ for $24 \mathrm{~h}$ and then milled in a pestle; the material passed through a $75 \mu \mathrm{m}$ sieve was used for the analyses. The clay brick waste (bricks discarded due to problems with dimensions, incorrect firing, or broken) was milled and sieved with a $75 \mu \mathrm{m}$ sieve, and then used in mortar and cement paste to verify the pozzolanic activity.

Characterization of raw clays: samples of the raw clays were prepared and characterized by $\mathrm{X}$-ray fluorescence (XRF) spectroscopy, X-ray diffraction (XRD), Fouriertransform infrared (FTIR) spectroscopy, thermal analysis (differential scanning calorimetry - DSC, and thermogravimetry - TG), and scanning electron microscopy (SEM). The qualitative phase composition was determined using an X-ray diffractometer (Shimadzu, XRD 6000) using $\mathrm{CuK} \alpha$ radiation, the chemical composition was determined using an XRF spectrometer (Philips, PW 2400), and a Perkin-Elmer (Spectrum One) equipment was used to evaluate the FTIR spectra in the range of $4000-560 \mathrm{~cm}^{-1}$. The microstructures of the raw clays were obtained using a scanning electron microscope (Hitachi, SU-70). The DSC/ TG tests were performed using a Netzsch (STA 449 C Jupiter) equipment from 10 to $1300{ }^{\circ} \mathrm{C}$ with a heating rate of $10{ }^{\circ} \mathrm{C} \cdot \mathrm{min}^{-1}$ and argon atmosphere.

Mortar preparation and testing: to evaluate the effect of the fired clay (brick waste - BW) in a common application in constructions, mortars without and with $40 \%$ of fired brick waste from industry B (BW-B, grain size $<75 \mu \mathrm{m}$, firing temperature about $800-900{ }^{\circ} \mathrm{C}$ ) were tested. The BW-B was chosen because, in the raw form, it presented the highest pozzolanic potential. A previous study [14] showed satisfactory results for $40 \%$ substitution, so this content was chosen in this study. The BW-B showed an average particle diameter of $6.04 \mu \mathrm{m}$, a BET surface area of $35.16 \mathrm{~m}^{2} / \mathrm{g}$, and the XRD analysis detected only the quartz phase. The proportion of materials used for mortars was, by volume, 1:1.5:6 (cement:lime:sand) commonly used in construction. This proportion was transformed from volume to mass. The cement used was type CPII-Z-32. The preparation of the mortars was carried out according to the NBR 13276 standard [15]. The amount of clay brick waste replacing the cement added to the mixture was calculated relative to the mass of the cement (Table II). The compressive strength test was performed according to the NBR 13279 standard

Table I - Information about the industries that supplied the clayey masses.

[Tabela I - Informações sobre as indústrias que forneceram as massas argilosas.]

\begin{tabular}{ccccc}
\hline Industry & $\mathrm{A}$ & $\mathrm{B}$ & $\mathrm{C}$ & $\mathrm{D}$ \\
\hline $\begin{array}{c}\text { Clayey ceramic } \\
\text { mass composition }\end{array}$ & $\begin{array}{c}83 \% \text { clay+17\% other } \\
\text { raw materials }\end{array}$ & $\begin{array}{c}85 \% \text { clay+15\% other } \\
\text { raw materials }\end{array}$ & $\begin{array}{c}30 \% \text { clay }+70 \% \text { other } \\
\text { raw materials }\end{array}$ & $\begin{array}{c}50 \% \text { clay }+50 \% \\
\text { other raw materials }\end{array}$ \\
$\begin{array}{c}\text { Annual production } \\
\text { of bricks }\end{array}$ & 7 million & 1.4 million & 2.16 million & 3 million \\
$\begin{array}{c}\text { Amount of } \\
\text { discarded bricks }\end{array}$ & $\begin{array}{c}1-5 \%(6000 \text { to } 30000 \\
\text { pieces/month })\end{array}$ & $1 \%(1200$ pieces $/$ month $)$ & $5 \%(9000$ pieces $/$ month $)$ & $2 \%(6000$ pieces $/$ month $)$ \\
\hline
\end{tabular}

Table II - Mass of components used to prepare $1.75 \mathrm{~L}$ of mortars.

[Tabela II - Massas dos componentes usados para preparação de 1,75 L de argamassas.]

\begin{tabular}{cccccc}
\hline Mortar & Cement $(\mathrm{g})$ & BW $75 \mu \mathrm{m}(\mathrm{g})$ & Lime $(\mathrm{g})$ & Sand $(\mathrm{g})$ & Water $(\mathrm{g})$ \\
\hline Reference & 157.6 & - & 163.6 & 1322.0 & 394.4 \\
M40BW & 86.7 & 57.8 & 190.7 & 1519.3 & 361.1 \\
\hline
\end{tabular}


[16]. For the analysis of SEM and EDS (energy dispersive spectroscopy), a cementitious matrix without sand (with $40 \% \mathrm{BW}$ ) was prepared to identify the possible hydration products present. The pastes used had the water to cement $(w / c)$ ratio of 0.5 .

\section{RESULTS AND DISCUSSION}

\section{Chemical and mineralogical characterizations}

Fig. 1 shows the XRD patterns of the raw clays A, $\mathrm{B}, \mathrm{C}$, and $\mathrm{D}$ as obtained after dry milling. The results of the analysis showed, for all samples, the major peaks corresponding to the phases kaolinite $\left[\mathrm{Al}_{2} \mathrm{Si}_{2} \mathrm{O}_{5}(\mathrm{OH})_{4}\right]$, halloysite $\left[\mathrm{Al}_{2} \mathrm{Si}_{2} \mathrm{O}_{5}(\mathrm{OH})_{4} \cdot 2 \mathrm{H}_{2} \mathrm{O}\right], \alpha$-quartz $\left(\mathrm{SiO}_{2}\right)$, gibbsite $\left[\mathrm{Al}(\mathrm{OH})_{3}\right]$, and hematite $\left(\mathrm{Fe}_{2} \mathrm{O}_{3}\right)[17,18]$. A previous study [19] related to the mineralogical characterization of the clays of the Santa Catarina State, Brazil, reported the absence of montmorillonite and the majority presence of kaolinite and halloysite in the samples.

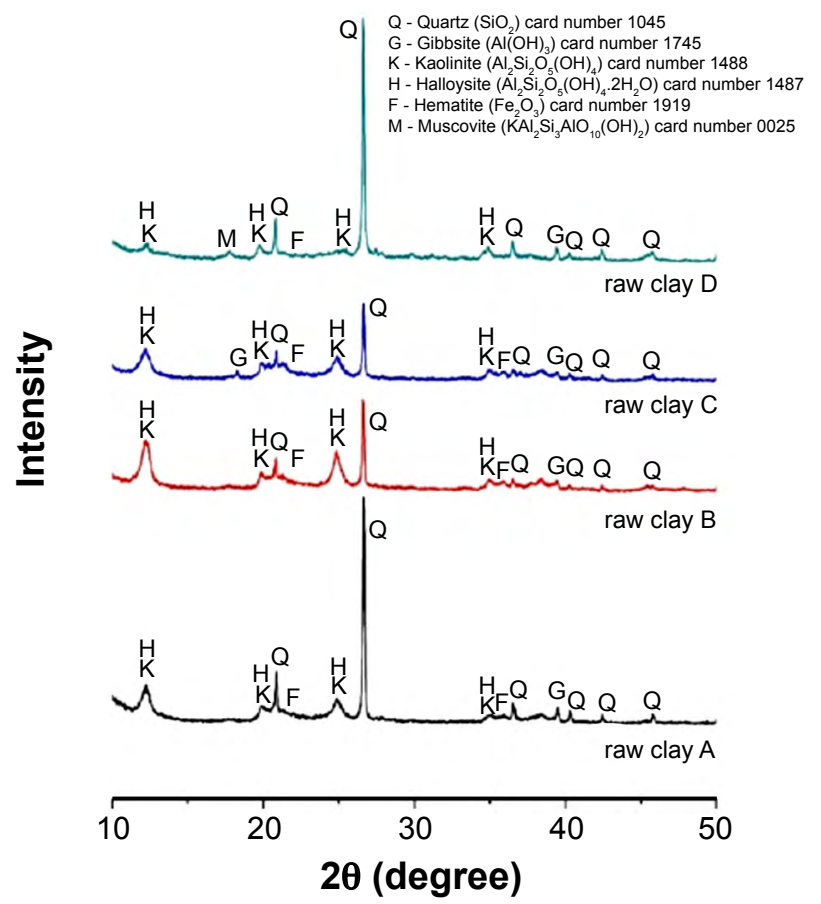

Figure 1: XRD patterns of in natura clayey ceramic masses A, B, $\mathrm{C}$, and D.

[Figura 1: Padrões de DRX das massas cerâmicas de argila in natura $A, B, C$ e $D$.

Table III shows the chemical composition of samples $\mathrm{A}, \mathrm{B}, \mathrm{C}$, and $\mathrm{D}$. The results showed the predominance of $\mathrm{Al}_{2} \mathrm{O}_{3}$ and $\mathrm{SiO}_{2}$ in all samples. The $\mathrm{Al}_{2} \mathrm{O}_{3}$ may be primarily associated with the kaolinite and halloysite clay minerals, as well as gibbsite, as observed in XRD patterns. The silica is present in the kaolinite and halloysite, and also associated with the quartz phase and probably feldspar, which was not observed in the XRD pattern. Likewise, the small amount of $\mathrm{K}_{2} \mathrm{O}$ in the chemical analysis may indicate the presence of small amounts of illite clay mineral and $\mathrm{K}$-feldspar in all samples, although not seen in XRD patterns. Other studies have reported similar results [20]. The molar ratio of $\mathrm{SiO}_{2} / \mathrm{Al}_{2} \mathrm{O}_{3}$ was 4.40 for the clay $\mathrm{A}$, which was higher than the theoretical molar ratio (2.00) of kaolinite (or halloysite). Molar ratios higher than the theoretical suggest the presence of quartz and other silicates in the samples [19]. Since the presence of feldspathic minerals was not observed, the results suggested that the clay A contained a large amount of free silica (quartz) as an impurity. As for the clay A, it was observed $\mathrm{Al}_{2} \mathrm{O}_{3}$ and $\mathrm{SiO}_{2}$, and also the other components, in clays $\mathrm{B}, \mathrm{C}$, and $\mathrm{D}$. The molar ratio of $\mathrm{SiO}_{2} / \mathrm{Al}_{2} \mathrm{O}_{3}$ was 3.07 for the clay $\mathrm{B}$, similar to the result of 3.03 for the clay $\mathrm{C}$. In the clay $\mathrm{D}$, a higher amount of $\mathrm{K}_{2} \mathrm{O}(3.59 \%)$ was observed compared to the clays $\mathrm{A}, \mathrm{B}$, and $\mathrm{C}$, indicating the presence of a small amount of a phase containing this element (illite or $\mathrm{K}$-feldspar, for example), although not seen in XRD pattern. The molar ratio of $\mathrm{SiO}_{2} / \mathrm{Al}_{2} \mathrm{O}_{3}$ was 4.97 for the clay $\mathrm{D}$, probably due to the high quartz content. Besides qualitative analysis by XRD to identify the mineralogical phases present in the samples, it is important to estimate the

Table III - Chemical composition (\% by mass) of raw clays $\mathrm{A}, \mathrm{B}, \mathrm{C}$, and D.

[Tabela III - Composição química (\% em massa) das argilas in natura $A, B, C$ e D.]

\begin{tabular}{ccccc}
\hline Oxide & $\mathrm{A}$ & $\mathrm{B}$ & $\mathrm{C}$ & $\mathrm{D}$ \\
\hline $\mathrm{SiO}_{2}$ & 58.53 & 49.76 & 47.14 & 59.67 \\
$\mathrm{Al}_{2} \mathrm{O}_{3}$ & 22.54 & 27.52 & 26.42 & 20.34 \\
$\mathrm{Fe}_{2} \mathrm{O}_{3}$ & 6.56 & 7.58 & 10.33 & 7.11 \\
$\mathrm{TiO}_{2}$ & 1.39 & 1.69 & 1.30 & 0.94 \\
$\mathrm{~K}_{2} \mathrm{O}$ & 0.77 & 0.88 & 0.56 & 3.59 \\
$\mathrm{CaO}$ & 0.20 & 0.18 & 0.17 & 0.09 \\
$\mathrm{MgO}$ & 0.54 & 0.34 & 0.40 & 1.03 \\
$\mathrm{Na}_{2} \mathrm{O}$ & 0.21 & 0.10 & 0.11 & 0.13 \\
$\mathrm{P}_{2} \mathrm{O}_{5}$ & 0.10 & 0.16 & 0.11 & 0.13 \\
$\mathrm{MnO}$ & 0.05 & 0.05 & 0.08 & 0.06 \\
LOI* & 9.10 & 11.74 & 13.39 & 6.56 \\
\hline *- loss on ignition. & & & &
\end{tabular}

Table IV - Quantification of the phases (\% by mass) present in raw clayey ceramic masses.

[Tabela IV - Quantificação de fases (\% em massa) presentes nas massas cerâmicas de argila in natura.]

\begin{tabular}{ccccc}
\hline Clay & $\begin{array}{c}\text { Kaolinite/ } \\
\text { halloysite }\end{array}$ & $\begin{array}{c}\text { Quartz } \\
\text { (impurity) }\end{array}$ & Hematite & Others* \\
\hline A & 57.1 & 32.0 & 6.5 & 4.4 \\
B & 69.7 & 17.3 & 7.6 & 5.4 \\
C & 66.9 & 16.1 & 10.3 & 6.7 \\
D & 51.5 & 35.7 & 7.1 & 5.7 \\
\hline
\end{tabular}

* - including gibbsite. 
amounts of the phases present. The content was estimated by the stoichiometry of the phases using the results of chemical and mineralogical analysis $[21,22]$. The results are shown in Table IV.

In samples that do not contain illite in its composition, the total amount of $\mathrm{Al}_{2} \mathrm{O}_{3}$ present can be attributed to kaolinite. The ideal composition of kaolinite is $46.5 \% \mathrm{SiO}_{2}+39.5 \%$ $\mathrm{Al}_{2} \mathrm{O}_{3}+13.96 \% \mathrm{H}_{2} \mathrm{O}$ [21]. Assuming that the samples had no illite and that the total amount of $\mathrm{Al}_{2} \mathrm{O}_{3}$ present in the sample was from kaolinite, it was possible to quantify the total amount of kaolinite in the samples. Likewise, it was possible to quantify the $\mathrm{SiO}_{2}$ content present in kaolinite of the sample. The amount of quartz as an impurity can be calculated by subtracting the total quantity of silica of the sample from the amount of silica in kaolinite. The excess $\mathrm{SiO}_{2}$ was attributed to the presence of quartz, as shown by XRD patterns. The contents of kaolinite and quartz as an impurity of all samples, calculated according to the method used in [23], are shown in Table IV. The samples A and D had the highest levels of quartz; sample B had the greatest amount of kaolinite $(69.7 \%)$ and $17.3 \%$ quartz as an impurity, results that were consistent with a $\mathrm{SiO}_{2} / \mathrm{Al}_{2} \mathrm{O}_{3}$ molar ratio of 3.07. Similar to sample B, sample $\mathrm{C}$ showed $66.9 \%$ kaolinite and the smallest amount of quartz as an impurity (16.1\%). The quantitative estimate of the phases of sample D was $51.5 \%$ kaolinite and halloysite, and $35.7 \%$ quartz. Materials that exhibit high silica content (generally above $50 \%$ ) and low amount of alumina (generally less than 25\%) are considered 'weak kaolin' [24]; a kaolinite rock is considered when the amount of kaolinite is higher than $50 \%$ [25]. Thus, all samples may be considered kaolinite, considering they showed amounts of kaolinite and halloysite higher than $50 \%$. The importance of estimating the kaolinite content in the material is justified by the fact that it affects the pozzolanic activity. The contents of kaolinite+halloysite of the raw clays in Table IV show that clay B had the highest potential to have pozzolanic activity with cement after firing, followed by clays C, A, and D. The presence of hematite in all samples is commonly found in masses of red ceramic. In this way, the amount of about $6.5 \%$ of hematite may come from the addition of red mud or is isomorphic substitutions of $\mathrm{Fe}$ in the clay structures, such as illite [23], which was not detected by the XRD. The presence of $\mathrm{TiO}_{2}$ also helps to provide color to the clay.

Fig. 2 shows the FTIR spectra of the 4 raw clays studied. The corresponding vibrations to hydroxyls present in the kaolinite and halloysite were shown in two bands at 3700 and $3620 \mathrm{~cm}^{-1}$. A difference between kaolinite and halloysite is that kaolinite has two slightly smaller bands between 3669 and $3652 \mathrm{~cm}^{-1}$ (Fig. 2b) [26]. Another difference is the shoulder of vibration from the surface hydroxyls of $\mathrm{Al}_{2} \mathrm{OH}$ groups at $939 \mathrm{~cm}^{-1}$ more prominent in kaolinite than in halloysite [27]. The bands at 3695 and $3622 \mathrm{~cm}^{-1}$ corresponded to the $\mathrm{OH}$ vibrations related to $\mathrm{Al}$ octahedral sheet. In addition, the vibrations of $\mathrm{Al}-\mathrm{OH}$ bonds were observed at $911 \mathrm{~cm}^{-1}$ [28]. The bands at 1002 and $1109 \mathrm{~cm}^{-1}$ were associated with the stretching of the $\mathrm{Si}-\mathrm{O}$ bond. Bands associated with $\mathrm{Si}-\mathrm{O}$ and $\mathrm{Si}-\mathrm{O}-\mathrm{Si}$ were observed at 1109 and $1027 \mathrm{~cm}^{-1}$ [28]. Also, the Si-O-Si asymmetric vibration mode was connected to the band at $1106 \mathrm{~cm}^{-1}$ [29]. Bands of Si-O bonds at $791,743,693,539$, and $464 \mathrm{~cm}^{-1}$ also indicated the presence of quartz [28]. Other features related to kaolinite bands mentioned in the literature [30] are: $\mathrm{OH}: 3700,3670$, 3650, $3620 \mathrm{~cm}^{-1}$; Al-OH: $913 \mathrm{~cm}^{-1}$; Si-O: 1115, 1032, 1008, $469 \mathrm{~cm}^{-1}$; Si-O-Al $: 789,754 \mathrm{~cm}^{-1}$; and $\mathrm{Si}-\mathrm{O}-\mathrm{Al}_{\mathrm{vI}}: 538 \mathrm{~cm}^{-1}$.

The Fig. 3 shows the most important physical and chemical phenomena according to the results of the thermal analysis (DSC/TG) for raw clays A, B, C, and D The thermal events were similar for all the samples, with small temperature variations, which are justified by the characteristics of each material (particle size, composition, etc.). The first peak (apparent in Fig. 3 when expanded) up to about $150{ }^{\circ} \mathrm{C}$ corresponded to the loss of adsorbed water [27], with mass loss of $1.27 \%$ for clay A, $0.55 \%$ for clay B, $1.40 \%$ for clay C, and $1.84 \%$ for clay D. The second peak
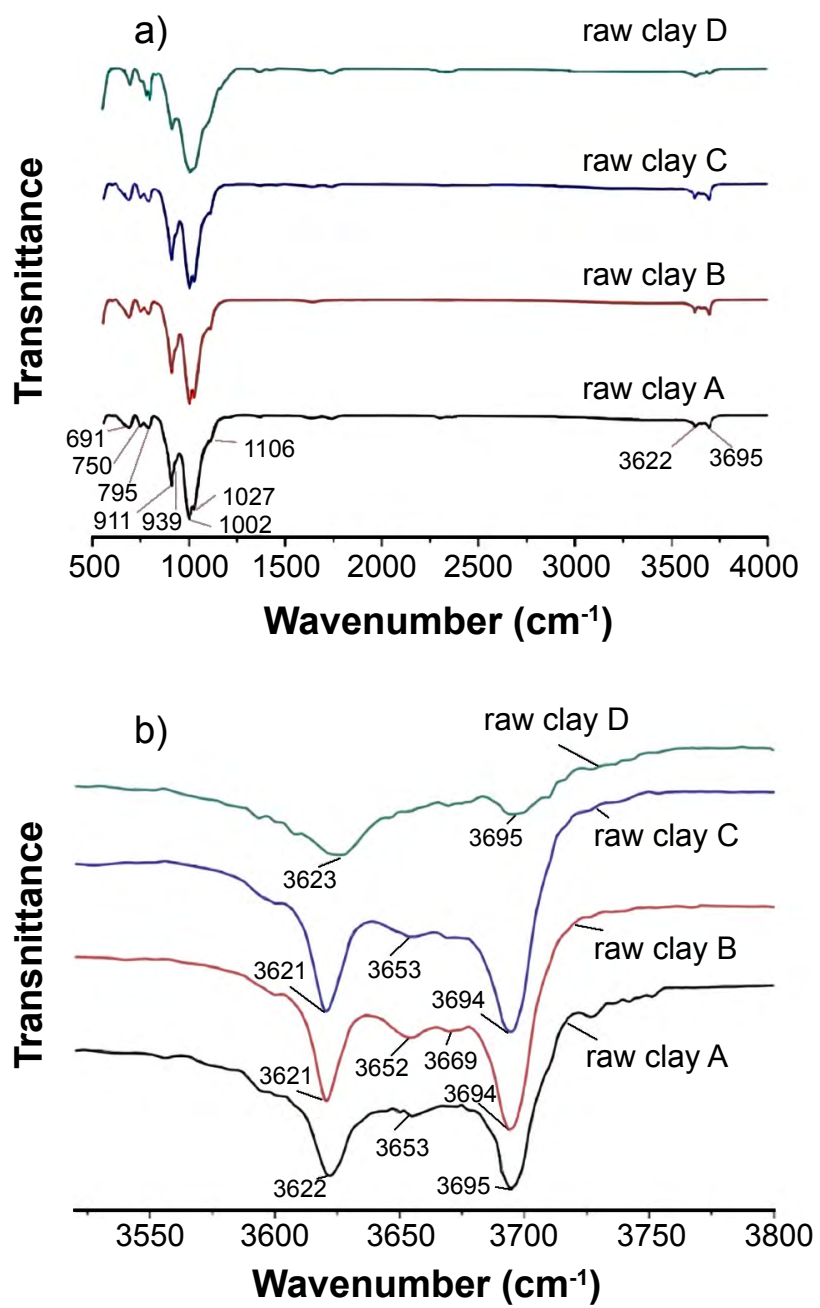

Figure 2: FTIR spectra of in natura clayey ceramic masses A, B, $\mathrm{C}$, and $\mathrm{D}$ in the range of 500 to $4000 \mathrm{~cm}^{-1}$ (a), and enlarged in the range of 3520 to $3800 \mathrm{~cm}^{-1}$ (b).

[Figura 2: Espectros de FTIR das massas cerâmicas de argila in natura A, B, C e D na faixa de 500 a $4000 \mathrm{~cm}^{-1}$ (a) e ampliados na faixa de 3520 a $3800 \mathrm{~cm}^{-1}($ b).] 
from 200 to $350{ }^{\circ} \mathrm{C}$ showed the gibbsite decomposition, shown in Fig. $3 \mathrm{c}$ for the clay C. The third peak corresponded to the dehydroxylation of the kaolinite and halloysite clay minerals with mass loss [27, 31, 32], associated with an endothermic peak in DSC curves at $474{ }^{\circ} \mathrm{C}$ for clay A, $483{ }^{\circ} \mathrm{C}$ for clay B, $479{ }^{\circ} \mathrm{C}$ for clay $\mathrm{C}$, and $473{ }^{\circ} \mathrm{C}$ for clay D. The endothermic dehydroxylation of kaolinite occurs between 450 and $600{ }^{\circ} \mathrm{C}$ producing disordered metakaolinite, but the loss of hydroxyls can continue up to $900{ }^{\circ} \mathrm{C}$ [33-35]. The theoretical mass loss of the dehydroxylation process for kaolinite is $13.96 \%$, considering the composition proposed $\left(46.5 \% \mathrm{SiO}_{2}+39.5 \% \mathrm{Al}_{2} \mathrm{O}_{3}+13.96 \%\right.$ $\mathrm{H}_{2} \mathrm{O}$ ) [21]. For the clay A (Fig. 3a), the mass loss considering the temperature of $650{ }^{\circ} \mathrm{C}\left(600{ }^{\circ} \mathrm{C}\right.$ is sufficient to occur the dehydroxylation [36]) was $8.21 \%$, already considering the amount of water lost until $150{ }^{\circ} \mathrm{C}$. The amount of kaolinite estimated for the clay A was $57.1 \%$, which would cause $~ 8 \%$ of mass loss. The difference between the values of the theoretical material and clay A was not significant and could be likely due to the other materials present in all the samples, such as quartz and hematite. For the clay B (Fig. 3b), with $69.7 \%$ of kaolinite ( $10 \%$ of expected theoretical loss), the observed mass loss at $650{ }^{\circ} \mathrm{C}$ was $11.51 \%$. This result confirmed that the clay B had a higher content of kaolinite and halloysite compared to the clay A. For the clay C (Fig. 3c), which contained $66.9 \%$ of kaolinite ( $\sim 9 \%$ of expected theoretical loss), the corresponding
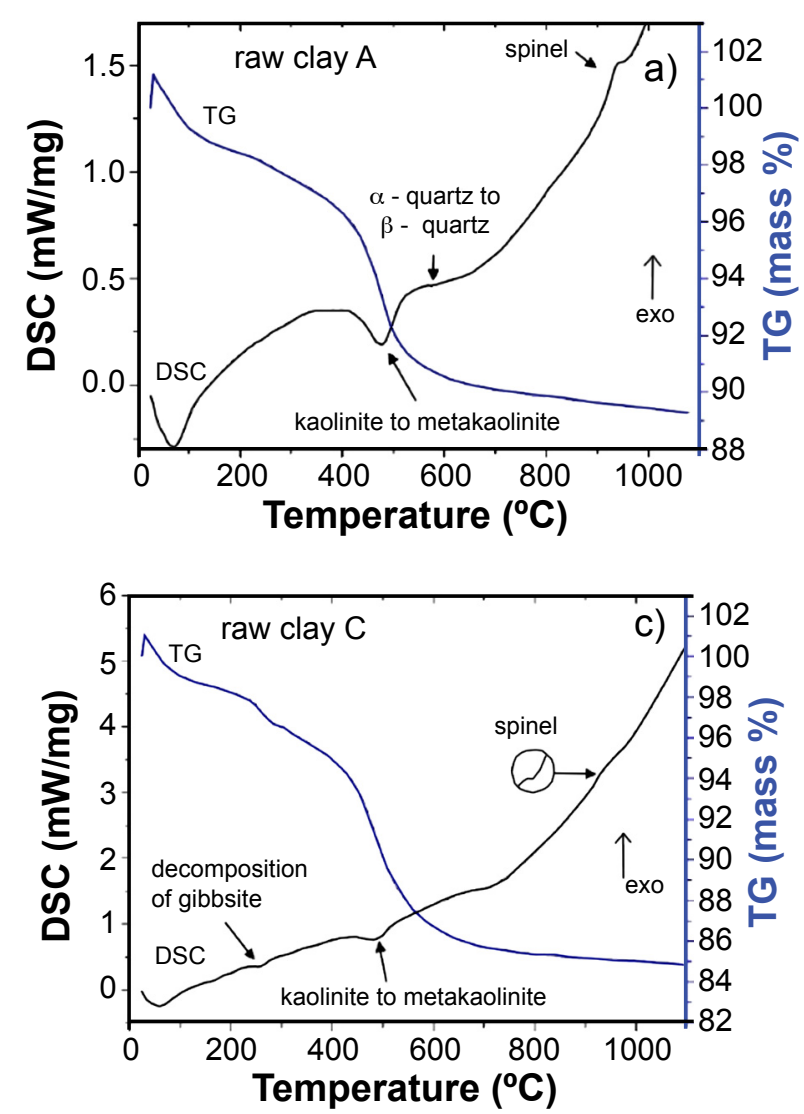

mass loss of the dehydroxylation was $11.87 \%$, similar to clay $\mathrm{B}$, but the process seemed to be less intense than the clays $\mathrm{A}$ and $\mathrm{B}$, indicating a difference in the formation of metakaolinite. Finally, for the clay D (Fig. 3d), with 51.5\% of kaolinite ( $7 \%$ of expected theoretical loss), the mass loss was $5.34 \%$. Only in this case, the observed mass loss was less than the theoretically calculated value and was much lower than the other samples. In the fourth event, at $573{ }^{\circ} \mathrm{C}, \alpha$-quartz transformed to $\beta$-quartz by a reversible change in the crystal structure with a linear expansion of $0.45 \%$. This reversal can lead to cracks in the ceramic if cooling occurs very rapidly [37]. In the fifth event with heating at $925-950^{\circ} \mathrm{C}$, the metakaolinite was converted to an aluminum-silicon spinel-type crystal structure. The exothermic peak at $970{ }^{\circ} \mathrm{C}$ can correspond to recrystallization, beginning of the formation of the spinel phase, which allows the formation of mullite at $1050-1100{ }^{\circ} \mathrm{C}$ [38]. Finally, after calcination above $1050{ }^{\circ} \mathrm{C}$, the nucleated spinel phase transformed to mullite with platelet shape and highly crystalline cristobalite [28]. It is well-known the amorphous form of metakaolinite. However, metakaolinite is not a simple mixture of amorphous silica and alumina, but rather a complex amorphous structure that retains some orders due to their hexagonal stacking layers [33]. The phenomena of the quartz phase change and formation of the spinel-type phase [37] were observed in all samples.
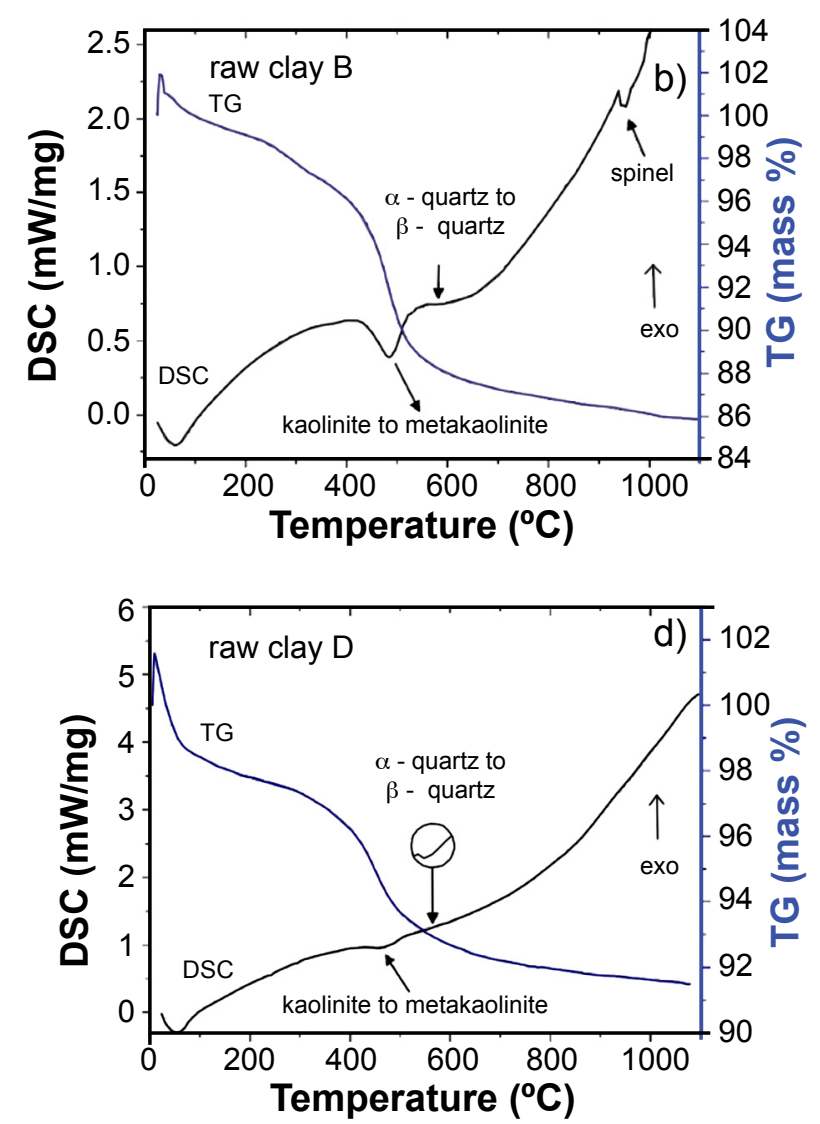

Figure 3: Differential scanning calorimetry (DSC) and thermogravimetric analysis (TG) curves of in natura clayey ceramic masses: a) A; b) B; c) C; and d) D).

[Figura 3: Curvas de calorimetria exploratória diferencial (DSC) e análise termogravimétrica (TG) das massas cerâmicas de argila in natura: a) $A$; b) $B$; c) $C$; e d) D.] 


\section{Morphological characterizations}

The kaolinitic clay minerals are usually present as plates in empty spaces, fractures, and breakups, possibly due to the discharge of hydrothermal fluids. It may also occur as hexagonal or pseudo-hexagonal crystals, exhibiting stacking layers [20]. Information on clay can be supplied by the knowledge of the geochemical environment during formation and diagenesis [39]. The amount of impurity (quartz, hematite, etc.) in the clay sample affects particle morphology [23]. The shape of the halloysite is of elongated tubes, while the shape of kaolinite is of stacked pseudo-hexagonal plates [40]. Raw clay samples A, B, C, and D, which showed 17-35\% quartz as impurity were analyzed by scanning electron microscopy (SEM), by secondary electrons, in order to evaluate possible differences in the morphology of phases (Fig. 4). The micrographs showed that kaolinite and halloysite were disorderly arranged and stacked, with crystals of different sizes and shapes, more or less agglomerated with some differences according to the clay. The morphologies observed by SEM was correlated with the XRD and FTIR results. The clay A showed layers of pseudo-hexagonal plates of kaolinite well-defined with sizes of about 100 to $500 \mathrm{~nm}$. The presence of a few tubular halloysite crystals was also observed, which may be an indication that clay A had a small amount of halloysite. No other morphologies were observed (well-defined crystals) of materials different from the clay minerals. Clay B had similar morphological characteristics to clay A, but with more irregular sheets, losing the hexagonal structure, and showing the presence of tubular halloysite structures. The microstructure of the clay $\mathrm{C}$ had similar characteristics to clay B; however, there was a greater presence of other minerals, affecting the ordering of layers. It was observed a higher concentration of tubular crystals in clay $\mathrm{C}$, indicating a higher concentration of halloysite in this clay. It was also observed the presence of materials with morphology different from the clay minerals, probably not crystalline materials. For clay $\mathrm{D}$, the same characteristics of the layers observed in the clay B were found. In this case, however, it was observed an agglomeration of materials whose morphologies were not related to the clay minerals. These materials were probably not crystalline materials from organic or inorganic impurities.

Fig. 5 shows an SEM image of the clay brick waste
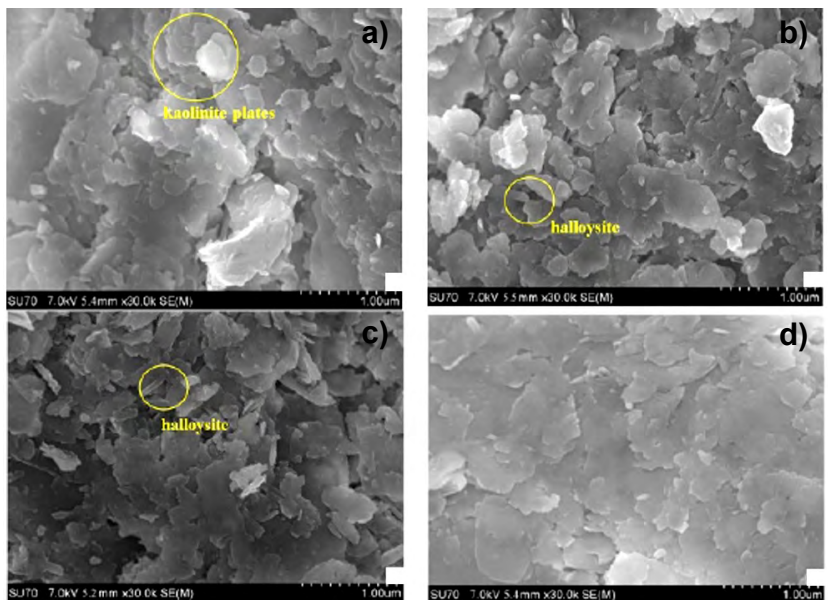

Figure 4: Micrographs obtained by SEM (secondary electrons) of in natura clayey ceramic masses: a) A; b) B; c) C; and d) D.

[Figura 4: Micrografias obtida por MEV (elétrons secundários) das massas cerâmicas de argila in natura: $a$ ) $A$; b) $B$; c) C; ed) D.]

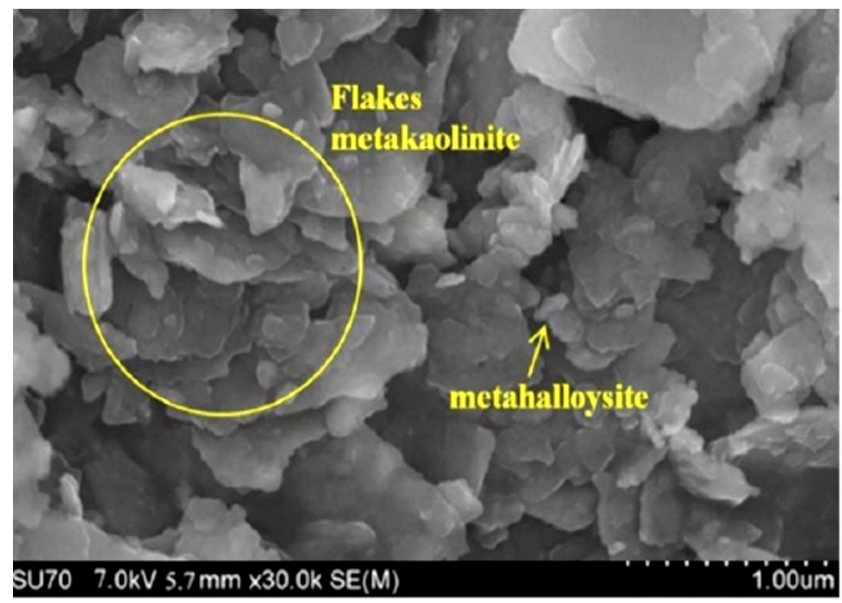

Figure 5: Micrograph obtained by SEM (secondary electrons) of clay brick waste B (after firing).

[Figura 5: Micrografia obtida por MEV (elétrons secundários) do resíduo de tijolo $B$ (após queima).]

$\mathrm{B}$, which was used to replace cement in a construction mortar. The halloysite microcrystals are smaller than those of kaolinite and have a longer profile. This was kept for metakaolinite and metahalloysite in calcined clays. A flake morphology corresponds to a part of the amorphous material. In clays containing low amounts of kaolinite and high amounts of impurities such as quartz, calcite, and muscovite, heat treatment has much less influence on morphology (as in the waste of fired clay brick) [41].

Table V - Properties of mortars.

[Tabela V - Propriedades das argamassas.]

\begin{tabular}{cccccc}
\hline Mortar & $\begin{array}{c}\text { BW } \\
(\%)\end{array}$ & w/c ratio & $\begin{array}{c}\text { Consistency index } \\
(\mathrm{mm})\end{array}$ & $\begin{array}{c}\text { Compressive } \\
\text { strength, 28 days } \\
(\mathrm{MPa})\end{array}$ & $\begin{array}{c}\text { Compressive } \\
\text { strength, 90 days } \\
(\mathrm{MPa})\end{array}$ \\
\hline Reference & 0 & 2.50 & 267 & $2.5 \pm 0.7$ & $5.7 \pm 0.4$ \\
M40\%BW & 40 & 2.50 & 190 & $6.4 \pm 0.2$ & $6.5 \pm 0.8$ \\
\hline
\end{tabular}

BW: brick waste; w/c: water/cement. 


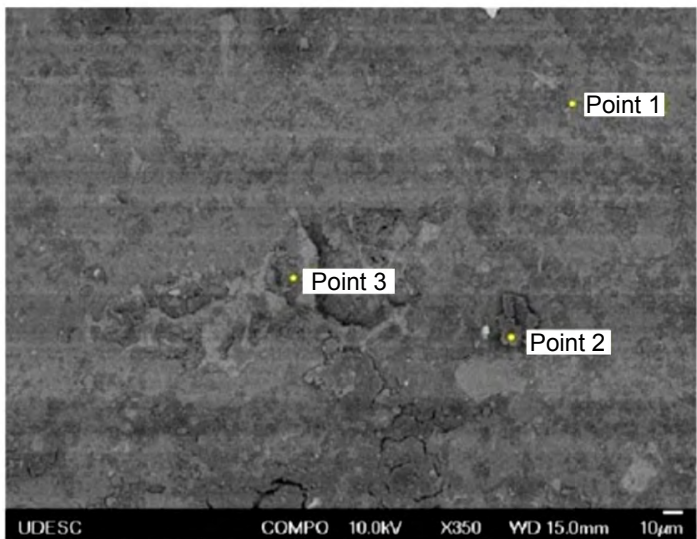

a)
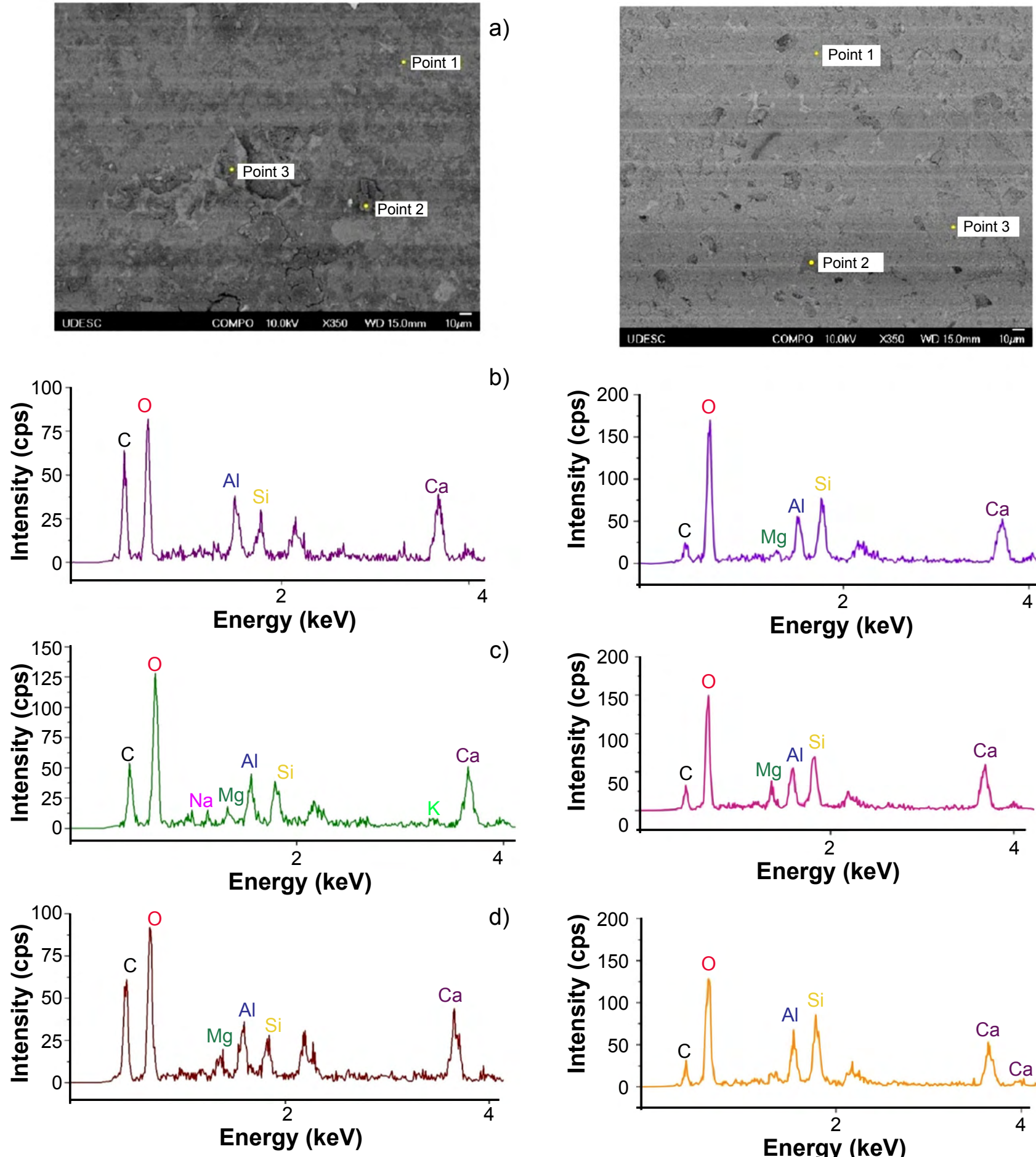

Figure 6: SEM micrograph (backscattered electron - BSE) of polished sample of M40\%BW paste at 28 days curing (a), and EDS spectra of the points 1 (b), 2 (c), and 3 (d).

[Figura 6: Micrografia de MEV (elétrons retroespalhados - BSE) de amostra polida da pasta $M 40 \% B W$ com 28 dias de cura (a) $e$ espectros de EDS dos pontos 1 (a), 2 (b) e 3 (d).]

Application of fired and ground clay (brick waste) in a construction mortar

Table $\mathrm{V}$ shows the properties of the construction mortars tested. The use of $40 \%$ of clay brick waste $(75 \mu \mathrm{m})$ replacing
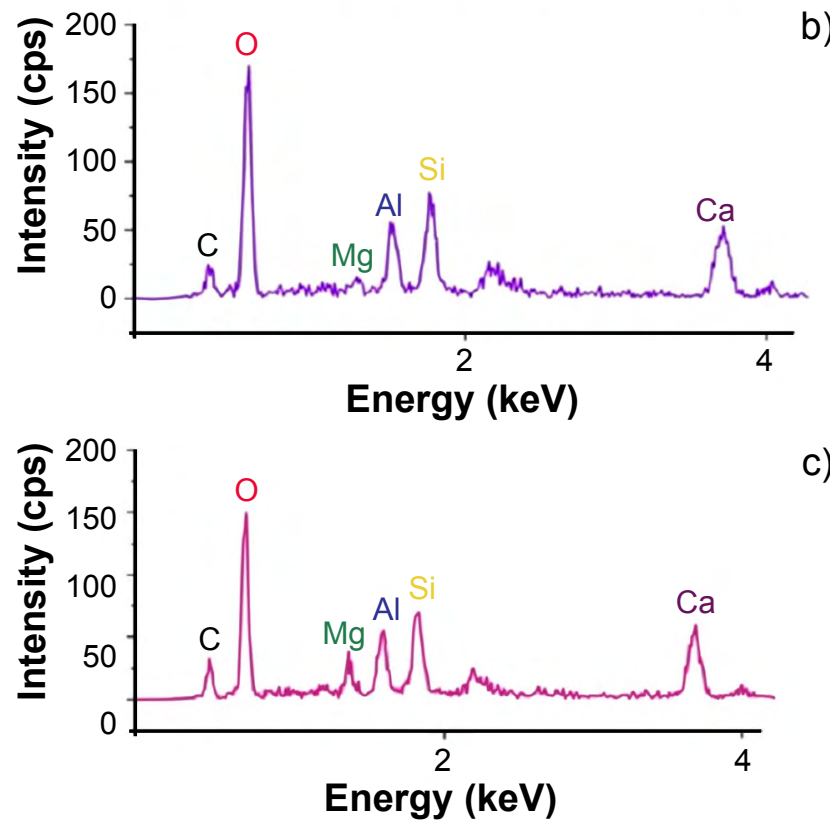

d)

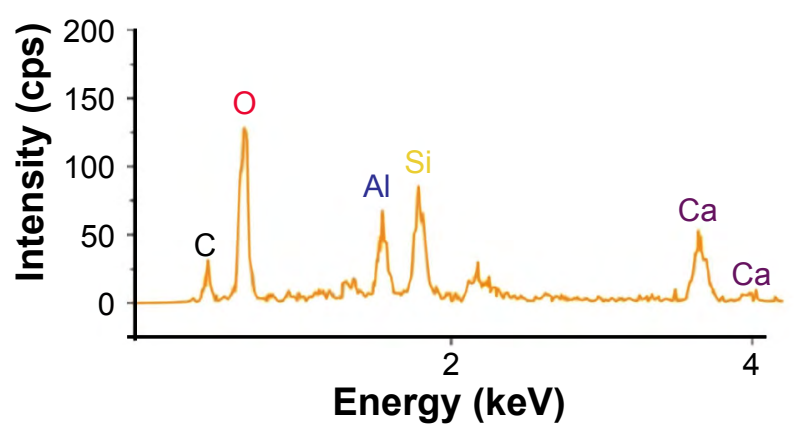

Figure 7: SEM-BSE image of another polished sample of M $40 \%$ BW paste at 28 days curing (a), and EDS spectra of the points 1 (b), 2 (c), and 3 (d).

[Figura 7: Imagem de MEV-BSE de outra amostra polida da pasta M40\%BW com 28 dias de cura (a) e espectros de EDS dos pontos $1(a), 2(b)$ e $3(d)$.]

Portland cement in a mortar resulted in a gain of $51 \%$ in compressive strength at 28 days. The use of CPII-Z-32 cement (with pozzolan) favored the increase of compressive strength at later ages in the reference mortar. The strength gain in the M40\%BW mortar between 28 and 90 days was 
Table VI - Results of semi-quantitative chemical analysis by EDS of points 1,2 and 3 indicated in Figs. 6 and 7. [Tabela VI - Resultados da análise química semiquantitativa por EDS dos pontos 1, 2 e 3 indicados nas Figs. 6 e 7.]

\begin{tabular}{ccccccccc}
\hline Figure & Point & $\mathrm{C}$ & $\mathrm{Na}$ & $\mathrm{MgO}$ & $\mathrm{Al}_{2} \mathrm{O}_{3}$ & $\mathrm{SiO}_{2}$ & $\mathrm{~K}_{2} \mathrm{O}$ & $\mathrm{CaO}$ \\
\hline \multirow{2}{*}{6} & 1 & 17.40 & - & - & 16.18 & 15.56 & - & 50.86 \\
& 2 & 12.58 & 1.13 & 3.15 & 12.24 & 17.45 & 3.58 & 49.87 \\
& 3 & 18.46 & - & 5.16 & 14.06 & 13.63 & - & 48.68 \\
\hline \multirow{2}{*}{7} & 1 & 5.09 & - & 2.50 & 15.32 & 28.51 & - & 48.58 \\
& 2 & 6.09 & - & 4.63 & 14.83 & 28.68 & - & 45.78 \\
& 3 & 5.77 & - & - & 14.57 & 34.18 & - & 45.48 \\
\hline
\end{tabular}

not so significant because the reference mortar had more pozzolanic cement. The clay brick waste had not only pure pozzolan but also impurities. This residue contributed to the mortar strength by the pozzolanic effect and also by the void filling effect. The reduction in the consistency due to water absorption by the waste clay brick also favored the strength in the M40\% BW mortar at 28 days.

Fig. 6a shows an SEM image of a polished surface of 28-day cured M40\%BW paste indicating the sites where the EDS analysis was conducted. In addition, Figs. 6b to $6 \mathrm{~d}$ show the EDS spectra of points 1,2, and 3 (Fig. 6a), and Table VI shows the results of the semi-quantitative chemical analysis of these points. The results of EDS analyses of points 1 and 3 were similar and revealed silicon, oxygen, calcium, and aluminum as major elements. The $\mathrm{Si} / \mathrm{Al}$ molar ratio was 0.88 at these two points. The $\mathrm{Si} / \mathrm{Al}$ molar ratio of metakaolinite $\left(\mathrm{Al}_{2} \mathrm{O}_{3} .2 \mathrm{SiO}_{2}\right)$ is 1.00 . Due to high amounts of $\mathrm{Ca}$ in these sites, it could be a particle of metakaolinite reacted with portlandite phase $\left[\mathrm{Ca}(\mathrm{OH})_{2}\right]$ forming other Portland cement hydration products. The $\mathrm{Ca} / \mathrm{Si}$ molar ratios of points 1 and 3 were not similar to those found for Portland cement hydration products, probably because the reactions were still in progress. The results of the qualitative and semiquantitative analyses of point 2 revealed silicon, oxygen, calcium, and aluminum as major elements, while potassium, magnesium, and sodium were found in small amounts. The $\mathrm{Si} / \mathrm{Al}$ molar ratio of point 2 was 1.30 , close to the $\mathrm{Si} / \mathrm{Al}$ molar ratio (1.00) of the metakaolinite. The difference of 0.30 can be attributed to the quartz contained in the clay brick waste. The small amounts of $\mathrm{Na}$ and $\mathrm{K}$ present may be from a ceramic phase, while $\mathrm{Ca}$ was related to a hydration product of the clay brick waste particle. Thus, point 2 may represent a metakaolinite particle that reacted to form C-S-H gel, although no other hydrated phases were detected, probably due to the progress of incomplete reactions. Three possible reactions can be proposed to represent the phenomenon [42]:

$$
\begin{aligned}
& \mathrm{AS}_{2}+6 \mathrm{CH}+9 \mathrm{H} \rightarrow \mathrm{C}_{4} \mathrm{AH}_{13}+2 \mathrm{CSH}_{\mathrm{I}} \\
& \mathrm{AS}_{2}+5 \mathrm{CH}+3 \mathrm{H} \rightarrow \mathrm{C}_{3} \mathrm{AH}_{6}+2 \mathrm{CSH}_{\mathrm{I}} \\
& \mathrm{AS}_{2}+3 \mathrm{CH}+7 \mathrm{H} \rightarrow \mathrm{C}_{2} \mathrm{ASH}_{8}+2 \mathrm{CSH}_{\mathrm{I}}
\end{aligned}
$$

where $\mathrm{A}=\mathrm{Al}_{2} \mathrm{O}_{3}, \mathrm{~S}=\mathrm{SiO}_{2}, \mathrm{C}=\mathrm{CaO}$, and $\mathrm{H}=\mathrm{H}_{2} \mathrm{O}$.
Fig. 7 shows another SEM image of a polished surface of the paste with clay brick waste and EDS spectra (Figs. $7 \mathrm{~b}$ to $7 \mathrm{~d}$ ) of the 3 points indicated on the micrograph (Fig. $7 \mathrm{a}$ ). According to the EDS results of point 1 (similar to point 2), it could probably be a grain of a crystalline phase containing mainly $(\mathrm{Ca}, \mathrm{Mg}) \mathrm{CO}_{3}$, calcium carbonate with $\mathrm{Mg}$ substituting $\mathrm{Ca}$ atoms in the crystal structure. The presence of Si may indicate that this phase reacted with metakaolinite $\left(\mathrm{Al}_{2} \mathrm{O}_{3} \cdot 2 \mathrm{SiO}_{2}\right)$ forming the $\mathrm{C}-\mathrm{S}-\mathrm{H}$ gel. The amounts of aluminum and magnesium determined by EDS of points 1 and 2 may indicate that these elements were incorporated in the C-S-H gel phase [43, 44]. The presence of magnesium may also be related to the hydrotalcite phase $\left[\mathrm{Mg}_{0.75} \mathrm{Al}_{0.25}(\mathrm{OH})_{2}\right]\left(\mathrm{CO}_{3}\right)_{0.125}\left(\mathrm{H}_{2} \mathrm{O}\right)_{0.5}$ [45]. The EDS of point 3 (Fig. 7d) indicated the main presence of $\mathrm{Ca}, \mathrm{Si}$, and $\mathrm{Al}$. The $\mathrm{Ca} / \mathrm{Si}$ molar ratio was 2.87 , close to the $\mathrm{Ca} / \mathrm{Si}$ molar ratio of 2.90 of the hydrated tetracyclic aluminate $\left(4 \mathrm{CaO} \cdot \mathrm{Al}_{2} \mathrm{O}_{3} \cdot 19 \mathrm{H}_{2} \mathrm{O}\right)$ cement phase.

\section{CONCLUSIONS}

Four types of in natura clayey ceramic masses from different ceramic industries of red bricks were characterized. The sample (raw material) with the highest potential for pozzolanic activity was identified and applied in replacement of Portland cement, in the form of clay brick waste powder (after firing). The determined characteristics can contribute to improving the production process and the final ceramic product in the industries. Knowing the exact temperature of dehydroxylation and mass loss can help improve the ceramic firing process and prevent cracking and failure. The temperature that occurred dehydroxylation of the kaolinite and halloysite clay minerals was $483{ }^{\circ} \mathrm{C}$ for the clay with the best characteristics to produce pozzolanic material ('clay B'). The analysis of the morphology of the raw clays showed the presence of pseudo-hexagonal plates of kaolinite and tubular crystals of halloysite, mainly in the raw clay B. The mass loss associated with dehydroxylation was $11.51 \%$ for clay $\mathrm{B}$, similar to a theoretical value considering stoichiometric kaolinite. The in natura clayey ceramic masses showed characteristics such as the content of kaolinite, halloysite, quartz, and hematite, and morphological properties favorable to produce a pozzolanic material. Clay B had the greatest amount of kaolinite (69.7\%). Qualitative analysis 
by XRD and FTIR contributed to the identification of the mineralogical phases present in the samples. The properties of the in natura (raw) clays influence the reactivity of the clayey ceramic masses after firing (clay brick waste). The higher amount of kaolinite and a lower amount of impurities, besides the morphology with a larger surface area (halloysite) in raw clay, can result in a ceramic material with higher pozzolanic potential after firing. The compressive strength at 28 days of mortar with $40 \%$ of fired brick waste (ground to $75 \mu \mathrm{m}$ ) produced from clay B, replacing Portland cement, improved $51 \%$ compared with the reference mortar. The analysis of the hydration products suggested the presence of $\mathrm{Al}_{2} \mathrm{O}_{3} .2 \mathrm{SiO}_{2}$ forming the $\mathrm{C}-\mathrm{S}-\mathrm{H}$ gel, hydrotalcite phase $\left[\mathrm{Mg}_{0.75} \mathrm{Al}_{0.25}(\mathrm{OH})_{2}\right]\left(\mathrm{CO}_{3}\right)_{0.125}\left(\mathrm{H}_{2} \mathrm{O}\right)_{0.5}$, and hydrated tetracyclic aluminate cement phase $\left(4 \mathrm{CaO} \cdot \mathrm{Al}_{2} \mathrm{O}_{3} \cdot 19 \mathrm{H}_{2} \mathrm{O}\right)$. There are two advantages to the environment when using ceramic brick wastes: reduction of the use of Portland cement $\left(\mathrm{CO}_{2}\right.$ emission reduction) and minimization of residue disposals.

\section{ACKNOWLEDGMENTS}

The authors appreciate the financial support received from the Santa Catarina State Research Agency FAPESC (Project 510-17), and are also grateful for the support of CAPES - Coordination of Improvement of Higher Education Personnel of the Brazilian Ministry of Education through the Doctoral Exchange Program at the University of Aveiro/ Portugal (Project 99999.013937/2013-08 - A. Schackow). We also thank the University of Aveiro for providing equipment and structure used for all the tests.

\section{REFERENCES}

[1] V. Beltran, E. Sanchez, J. Garcia, F. Fernando, Tile Brick Int. 12 (1996) 320.

[2] P. Sánchez-Soto, J. Diaz-Hernandez, M. RaigónPichardo, A. Ruiz-Conde, G. Garcia-Ramos, Br. Ceram. Trans. 93 (1994) 196.

[3] J. Oti, J. Kinuthia, J. Bai, Eng. Geol. 107 (2009) 130.

[4] G.W. Brindley, G. Brown (Eds.), "Crystal structures of clay minerals and their X-ray identification" 5, Miner. Soc. Great Brit. Ireland (1980).

[5] J. Konta, Appl. Clay Sci. 10 (1995) 275.

[6] D.M. Moore, R.C. Reynolds, X-ray diffraction and the identification and analysis of clay minerals, Oxford Un. Press, Oxford (1989).

[7] H.M. Fentaw, T. Mengistu, Appl. Clay Sci. 13 (1998) 149.

[8] W.M. Carty, U. Senapati, J. Am. Ceram. Soc. 81 (1998) 3.

[9] G. Ballas, S. Garziglia, N. Sultan, E. Pelleter, S. Toucanne, T. Marsset, V. Riboulot, S. Ker, Eng. Geol. 240 (2018) 175.

[10] F. Deschner, F. Winnefeld, B. Lothenbach, S. Seufert, P. Schwesig, S. Dittrich, F. Goetz-Neunhoeffer, J. Neubauer, Cem. Concr. Res. 42 (2012) 1389.
[11] R. Silva, J. de Brito, R. Dhir, Constr. Build. Mater. 105 (2016) 400.

[12] K.L. Lin, B.Y. Chen, C.S. Chiou, A. Cheng, Waste Manag. Res. 28 (2010) 647.

[13] S. Subasi, H. Öztürk, M. Emiroglu, Constr. Build. Mater. 149 (2017) 567.

[14] A. Schackow, D. Stringari, L. Senff, S.L. Correia, A.M. Segadães, Cem. Concr. Compos. 62 (2015) 82.

[15] ABNT NBR 13276, "Mortars applied on walls and ceilings: determination of consistency index", Braz. Ass. Techn. Stand., Rio Janeiro (2005).

[16] ABNT NBR13279, "Mortars applied on walls and ceilings: determination of flexural and compressive strength in the hardened stage", Braz. Ass. Techn. Stand., Rio Janeiro (2005).

[17] B. Szczepanik, P. Slomkiewicz, M. Garnuszek, K. Czech, D. Bana, A. Kubala-Kuku, I. Stabrawa, J. Mol. Struct. 1084 (2015) 16.

[18] H. Tchakoute, C. Rüscher, J. Djobo, B. Kenne, D. Njopwouo, Appl. Clay Sci. 107 (2015) 188.

[19] S.L. Correia, K. Curto, D. Hotza, A.M. Segadães, Mater. Sci. Forum 498 (2005) 447.

[20] S. Kadir, H. Erman, H. Erkoyun, Clay Miner. 59 (2011) 250.

[21] A.C.D. Newman (Ed.), in "Chemistry of clays and clays minerals", Miner. Soc. Monogr. 6, Longman, London (1987) 2.

[22] C. Coelho, N. Roqueiro, D. Hotza, Mater. Lett. 52 (2002) 394.

[23] M. Felhi, A. Tlili, M. Gaied, M. Montacer, Appl. Clay Sci. 39 (2008) 208.

[24] M. Dondi, G. Guarini, P. Ligas, M. Palomba, M. Raimondo, Appl. Clay Sci. 18 (2001) 145.

[25] T. Dombrowski, in "Science of whitewares II", W.M. Carty, C.W. Sinton (Eds.), Am. Ceram. Soc., Westerville (2000) 3.

[26] G. Nirmala, G. Viruthagiri, Spectrochim. Acta A 135 (2015) 76.

[27] L. Zatta, "Kaolinite and halloysite in-nature and activated with acids minerals as heterogeneous catalysts for ethylic esterification of fatty acid", Master Thesis, Fed. Un. Parana (2010).

[28] M.B. Ogundiran, S. Kumar, Appl. Clay Sci. 108 (2015) 173.

[29] L. Deng, Z. Shi, J. Alloys Compd. 637 (2015) 188.

[30] J.D. Russel, in "Laboratory methods in infrared spectroscopy", H. Willis (Ed.), Wiley, New York (1987).

[31] C. Bich, J. Ambroise, J. Péra, Appl. Clay Sci. 44 (2009) 194.

[32] T. Zhang, X. Yue, Y. Deng, D. Zhang, S. Liu, Constr. Build. Mater. 73 (2014) 51.

[33] M. Bellotto, A. Gualtieri, G. Artioli, S. Clark, Phys. Chem. Miner. 22 (1995) 207.

[34] A.M. Neville, J.J. Brooks, Concrete technology, Bookman (2013).

[35] M.F. Nuruddin, S.U. Khan, N. Shafiq, Appl. Mech. Mater. 567 (2014) 375. 
[36] A. Chakchouk, B. Samet, T. Mnif, Appl. Clay Sci. 33 (2006) 79.

[37] A. Dodd, D. Murfin, Dictionary of ceramics, $3^{\text {rd }}$ ed., Inst. Miner., London (1994).

[38] V. Mymrin, W. Klitzke, K. Alekseev, R.E. Catai, A. Nagalli, R.L.S. Izzo, C.A. Romano, Appl. Clay Sci. 107 (2015) 28.

[39] Y.Z. Chen, W.H. Zhou, F. Liu, S. Yi, X. Geng, Eng. Geol. 256 (2019) 84.

[40] H.H. Murray, Applied clay mineralogy: occurrences, processing and applications of kaolins, bentonites, palygorskite-sepiolite, and common clays, Elsevier (2007).
[41] S. Selmani, N. Essaidi, F. Gouny, S. Bouaziz, E. Joussein, A. Driss, A. Sdiri, S. Rossignol, J. Afr. Earth Sci. 103 (2015) 113.

[42] R. Siddique, J. Klaus, Appl. Clay Sci. 43 (2009) 392.

[43] P.D. Tennis, H.M. Jennings, Cem. Concr. Res. 30 (2000) 855.

[44] C. Famy, K. Scrivener, A. Crumbie, Cem. Concr. Res. 32 (2002) 1465.

[45] G.C. Isaia, M.A. Cincotto, Concrete: science and technology, Ibracon, Brazil (2011).

(Rec. 11/09/2019, Rev. 05/11/2019, 17/12/2019, Ac. 20/12/2019) 